\title{
Defining the coast and sentinel ecosystems for coastal observations of global change
}

\author{
Stefano Mazzilli · Robert R. Christian
}

Published online: 20 March 2007

(C) Springer Science+Business Media B.V. 2007

Erratum to: Hydrobiologia (2007) 577: 55-70

DOI 10.1007/s10750-006-0417-4

The authors of this article were printed in the wrong order. The correct order is given here. The publishers apologise for this error.

The online version of the original article can be found at http://dx.doi.org/10.1007/s10750-006-0417-4

Guest editors: P. Viaroli, P. Lasserre \& P. Campostrini Lagoons and Coastal Wetlands in the Global Change

Context: Impacts and Management Issues

\section{S. Mazzilli}

Global Terrestrial Observing System/Environment and Natural Resources Service, Food and Agricultural Organization of the United Nations, Rome 00185, Italy

R. R. Christian ( $₫)$

Global Terrestrial Observing System/Biology

Department, East Carolina University, Greenville,

NC 27858, USA

e-mail: christianr@ecu.edu 